\title{
Ground stone tools from the copper production site Al- Khashbah, Sultanate of Oman
}

\author{
Stephanie Döpper \\ Institute for Archaeological Sciences, Goethe University Frankfurt. Norbert-Wollheim-Platz 1, 60629 Frankfurt \\ am Main, Germany. Email: doepper@em.uni-frankfurt.de
}

\begin{abstract}
:
Archaeological research at Al-Khashbah, Sultanate of Oman, conducted by the University of Tübingen, revealed a large Early Bronze Age ( $3^{\text {rd }}$ millennium BCE) site. During the intensive surface survey and excavations, several ground stone tools were found. Most of them came from the vicinity of monumental stone and mud-brick structures, so-called towers, and are clearly connected to copperprocessing waste such as slag, furnace fragments and prills, i.e., droplets of molten copper. Therefore, it is assumed that these ground stone tools were used within the operational procedures of copperprocessing. Interestingly, only the monumental towers from the first half of the $3^{\text {rd }}$ millennium BCE, i.e., the Hafit period, feature largef quantities of ground stone tools as well as copper processing waste. Towers from the second half of the $3^{\text {rd }}$ millennium BCE, i.e., the Umm an-Nar period, have none. Within the scope of this paper, the distribution of the different types of ground stone tools in $\mathrm{Al}$ Khashbah as well as their find context will be presented. They are illustrated with drawings generated from 3D models created using digital photography processed with the software Agisoft Photoscan. Comparisons with other $3^{\text {rd }}$ millennium BCE sites in Eastern Arabia show that there as well, copperprocessing remains are often associated with ground stone tools. The overall variety of types seems to be rather homogeneous in the region.
\end{abstract}

Keywords: Al-Khashbah; copper production; ground stone tools; Early Bronze Age; Oman; Eastern Arabia

\section{Introduction}

In 2015, a new archaeological research project from the University of Tübingen, funded by the German Research Foundation, was launched in Al-Khashbah, Sultanate of Oman, in order to investigate the fundamental social and economic changes that occurred during the $3^{\text {rd }}$ millennium BCE in Eastern Arabia (Schmidt \& Döpper 2017a; b). Al-Khashbah is situated in central Oman, south of the main mountain range, the Al-Hajar Mountains, about $16 \mathrm{~km}$ to the north of the modern city of Sinaw in the Ash-Sharqiya governorate (Figure 1). Archaeological remains, among them more than 200 tombs and at least 10 monumental stone or mud-brick buildings, so-called towers in the archaeological terminology of the region, are spread out over an area of approximately 5 x 2.5 kilometres.

Published by the School of History, Classics and Archaeology, University of Edinburgh ISSN: 2055-0472. URL: http://journals.ed.ac.uk/lithicstudies/ 


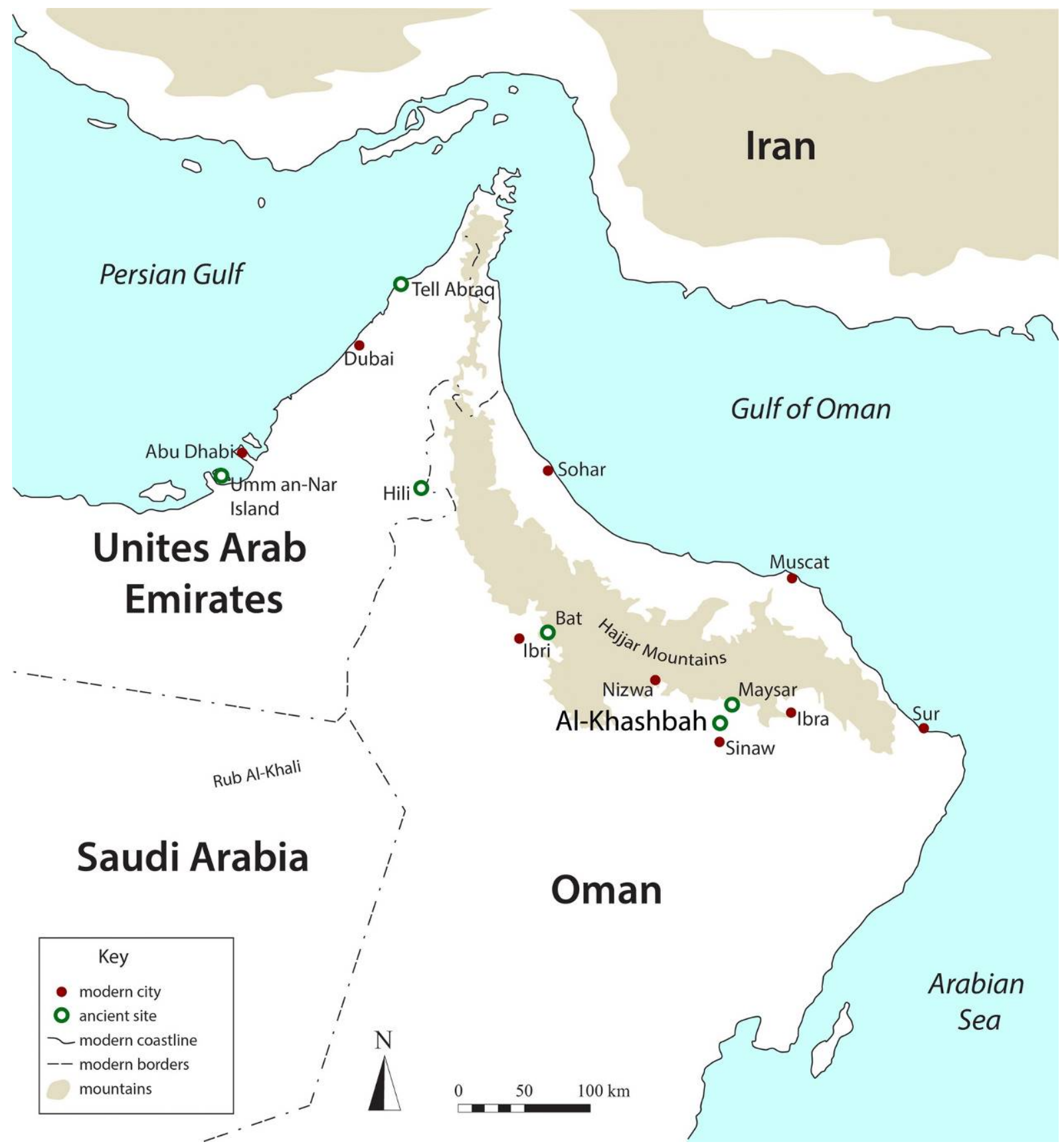

Figure 1. Map of Oman with Al-Khashbah and other sites mentioned in the text.

Al-Khashbah (Figure 2) is long known as an important site of the $3^{\text {rd }}$ millennium BCE in Oman because of its well preserved and unique rectangular building, Building IV (Figure 2), but has been only briefly surveyed (Al-Jahwari 2013; Al-Jahwari \& Kennet 2010: 203-207; Weisgerber 1980: 99-100; Yule 2001: 384) prior to the beginning of the University of Tübingen's project in 2015. Intensive pedestrian and geophysical surveys as well as excavations at selected areas were carried out during the past three seasons, mainly revealing remains of the Early Bronze Age. The pedestrian survey covered an area of more than 20 ha in total, which were field walked at $1 \mathrm{~m}$ spaced intervals in order to guarantee a complete coverage of the surface. In total, 18.000 objects were recorded during this survey. Besides some test investigations at Building II (Figure 2), excavations focussed on the oldest known remains at Al-Khasbhah: Building I and Building V, where five nine-week seasons have been carried out between 2015 and 2019. Within the scope of this paper, three Early Bronze Age 
monumental buildings are of particular interest. These are Building I in the western part of the site as well as Building IV and Building V in the central part of the site (Figure 2). All of them date to the $3^{\text {rd }}$ millennium BCE, wherein Building I and Building $\mathrm{V}$ date to the earlier part of the $3^{\text {rd }}$ millennium BCE, the so-called Hafit period (3100-2700 BCE), and Building IV to the later part, the so-called Umm an-Nar period (2700-2000 BCE). Other Hafit period monumental buildings in Al-Khashbah are Building VI, VIII, and IX. The buildings II, III, and VII date to the Umm an-Nar period. After the $3^{\text {rd }}$ millennium BCE, Al-Khashbah was widely abandoned and only six subterranean tombs of the Wadi Suq period (2000-1600 BCE) are representing the $2^{\text {nd }}$ millennium BCE. Afterwards, Al-Khashbah remains unoccupied until the Islamic period.

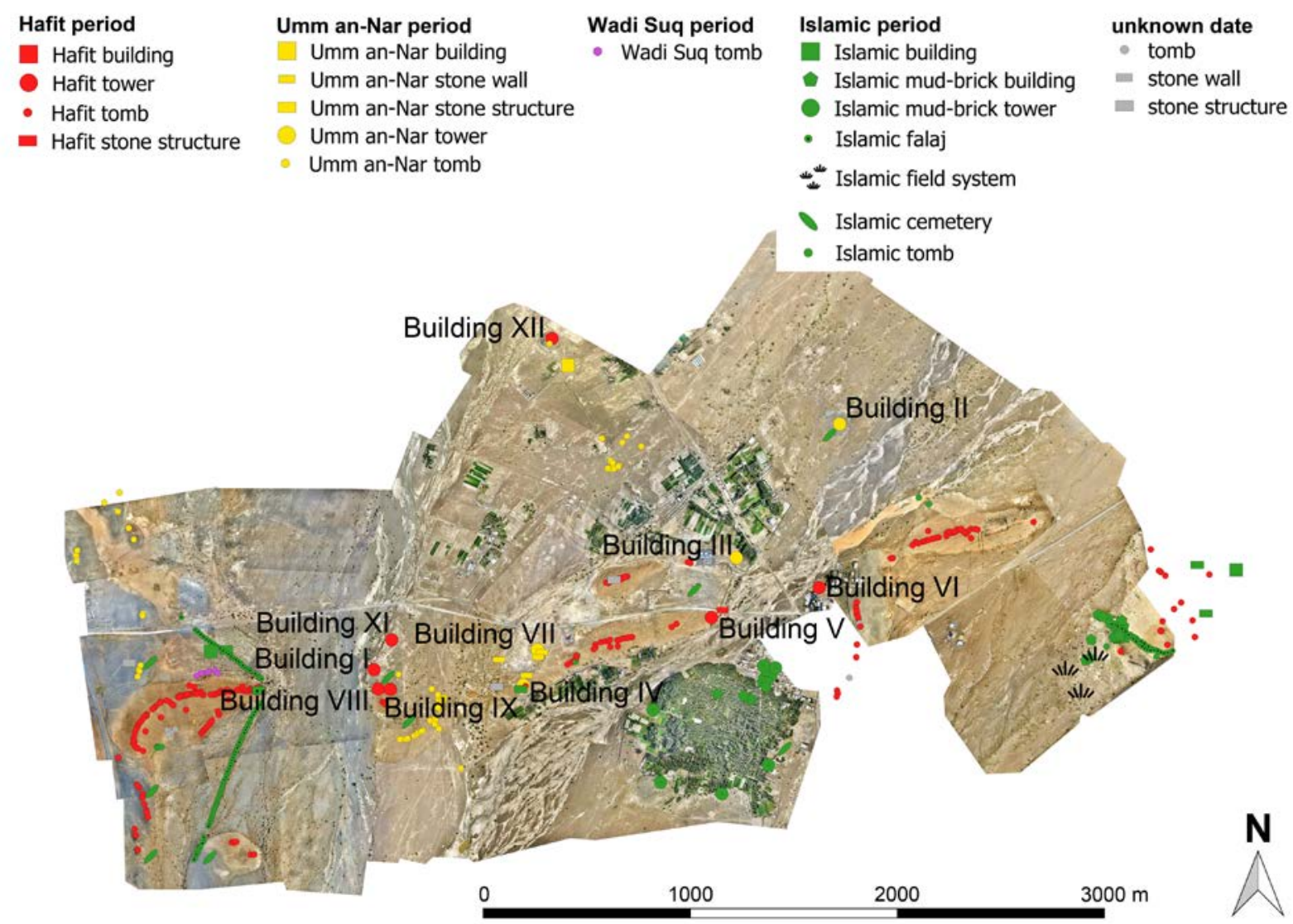

Figure 2. Map of Al-Khashbah with Building I, Building II, Building IV and Building V (Map: Al-Khashbah Project).

\subsection{Building I}

The area of Building $\mathrm{I}$ is characterized by a small elevation about $1 \mathrm{~m}$ in height next to a wadi. Pedestrian surface surveys revealed large quantities of slag as well as some furnace fragments in addition to many fragments of flint tools and their production debris (Figure 3). This indicates that during the Early Bronze Age the area served as a place for copper processing and the production of flint stone tools. Excavations brought to light a large mudbrick complex surrounded by ditch systems measuring approximately 80 by $80 \mathrm{~m}$. Its subrectangular ditches are $3 \mathrm{~m}$ deep and $4 \mathrm{~m}$ wide. They encompass different mud-brick buildings, which mainly consist of small, regular rooms with combinations of mud-brick and stone walls. The overall layout and especially the function of these structures are not completely understood yet, but they can perhaps be interpreted as what is called a tower in the archaeological terminology of the region: a monumental building, circular in plan, whose 
function is debated. Interpretations range from defensive structures, or keeps, for protection against hostilities (Frifelt 1976: 59; Weisgerber 1981: 198-204) to residences of elites (Cleuziou \& Tosi 2007: 147), resting places at a distance of a day's ride (Frifelt 2002: 109), market places (Frifelt 2002: 110), structures associated with irrigation (Cleuziou 2009; Frifelt 1989: 113; 2002: 104) and cultic structures (Hastings et al. 1976: 13; Orchard \& Orchard 2002: 230-232; Reade 2000: 135-136). A series of 10 radiocarbon dates provide a coherent date for Building I around 2800 BCE (Schmidt \& Döpper 2017a: fig. 14).

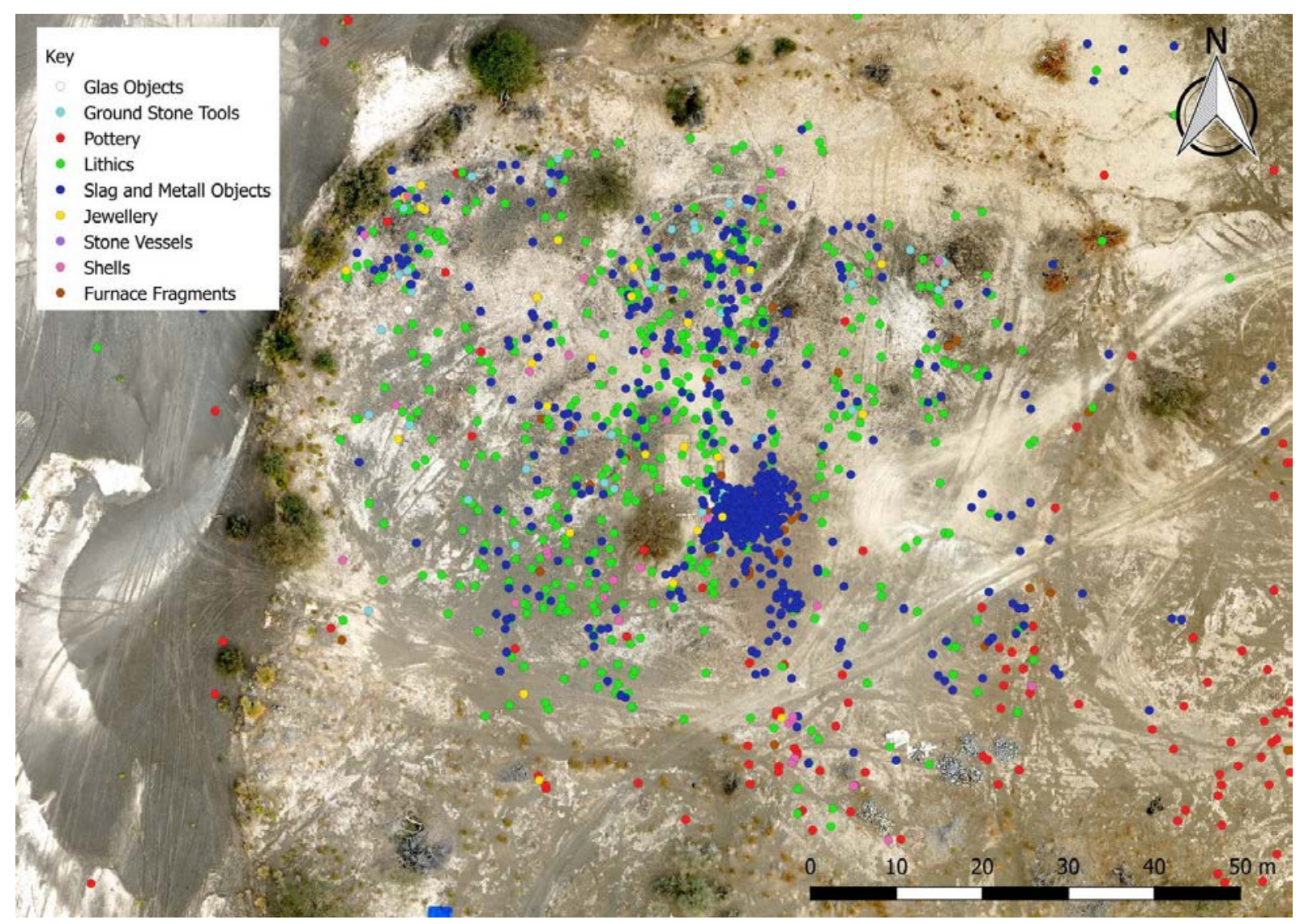

Figure 3. Building I: Results of pedestrian survey (Map: Al-Khashbah Project). The extent of Building I is beyond the limits of excavation and therefore still unclear.

\subsection{Building $\mathrm{V}$}

Building $\mathrm{V}$ is another monumental complex from the very beginning of the Early Bronze Age, dating to the end of the 4th millennium BCE according to radiocarbon dates (Schmidt \& Döpper 2017a: fig. 9). It is a round stone-built tower with a diameter of $25 \mathrm{~m}$ and several annexes to the south. The 2015 pedestrian surface survey revealed large amounts of slag and oven fragments from its surface. In the excavations to the south of the building and in its interior, further quantities of slag, furnace fragments and copper debris emerged (Figure 4). This clearly indicates that copper processing was the main activity carried out here.

\subsection{Building IV}

The most famous building of Al-Khashbah is Building IV. It is seemingly unique as it is the only rectangular tower of the $3^{\text {rd }}$ millennium BCE known from Eastern Arabia. All other towers investigated by archaeologists so far have a round ground plan. Its four sides are about equal in length, measuring 29.5 to $30.0 \mathrm{~m}$. Here, only Umm an-Nar (2700-2000 BCE) pottery was found on the surface during the pedestrian survey, namely beige on buff domestic ware 
with a typical decoration of straight and wavy lines (Figure 5). This was complemented by a few slag and furnace fragments.

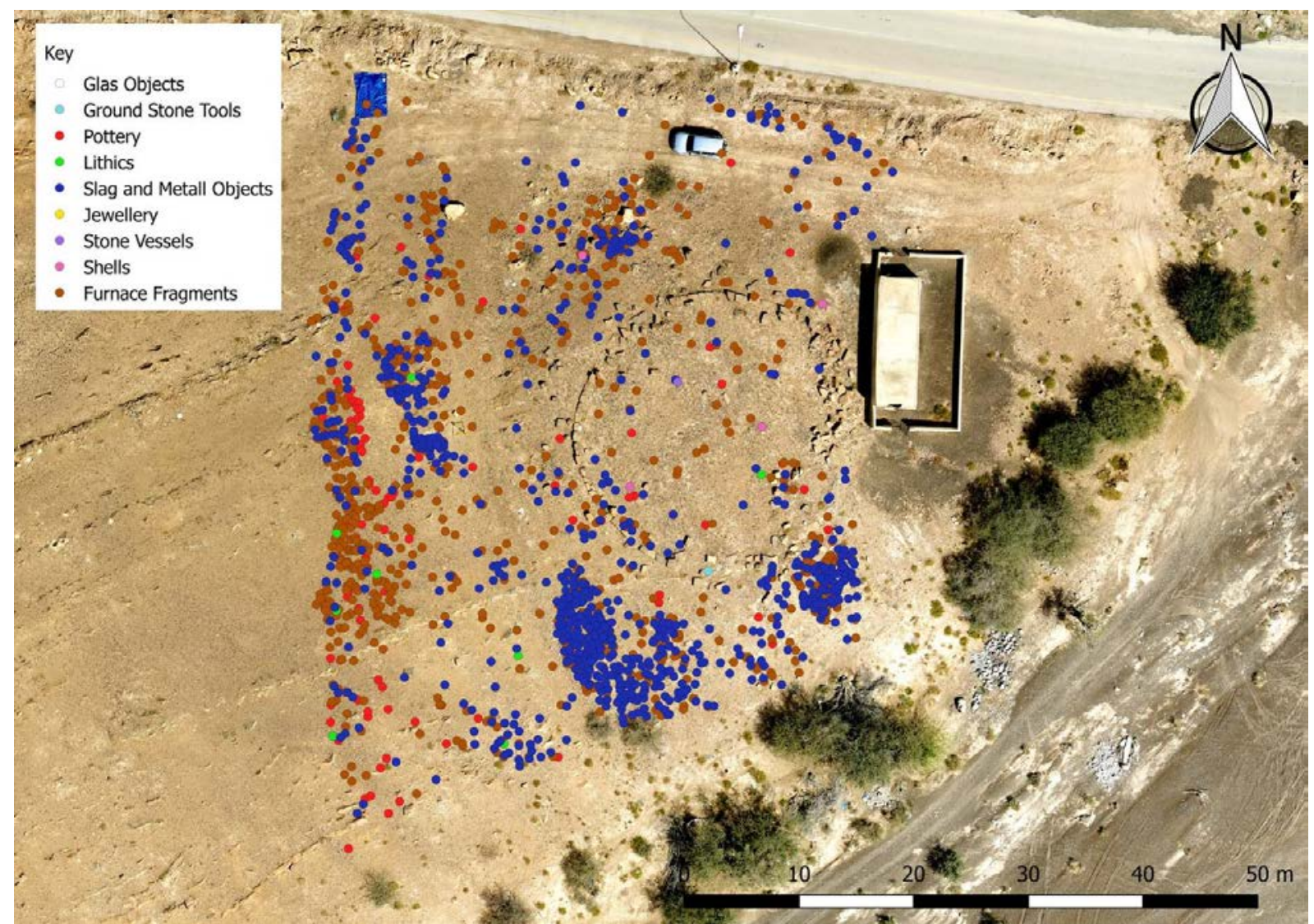

Figure 4. Building V: Results of pedestrian survey (Map: Al-Khashbah Project). Northern, eastern and southern boundaries of the survey area were limited by modern constructions and the wadi, the western boundary by the artificial grid system of the Al-Khashbah project. The circular outer wall of Building $\mathrm{V}$ is well visible on the map, its total extent, however, is still unknown.

Apart from the $3^{\text {rd }}$ millennium BCE remains at the tower, about 100 petroglyphs were documented, which had been picked into the stone blocks of the walls. The motifs are numerous and range from riders on camels and horses, men with raised arms, to a variety of symbols and geometric motifs (Schmidt \& Döpper 2017a: 218). Most of the petroglyphs were found on the north-eastern corner of the building, where the wall is preserved to a height of up to $2.20 \mathrm{~m}$. The petroglyphs are most likely only a few hundred years old, and therefore much younger than the building itself (Schmidt \& Döpper 2017a: 218).

\section{Methodological framework}

All ground stone tools found during the pedestrian surveys or excavations in AlKhashbah, carried out by the Al-Khashbah project since 2015 under the direction of Conrad Schmidt (Schmidt \& Döpper 2017a; b), were given an ascending find number, attributed to an archaeological unit, and their find spot was located within the global UTM system using a total station or hand-held GPS. In total, 134 ground stone tools were recorded. In the excavation house, the object's information was entered into a database, including the measurements of their maximum preserved length, width, thickness, and weight, as well as a detailed description of their shape and the appearance of the worked surface and use-wear visible to the naked eye. The ground stone tools were classified within the project's typology, which primarily divides between stone tools with evidence for grinding, polishing and 
percussion activities and records the shape of the longitudinal and transverse sections. A determination of the raw materials of the objects is still work in progress and can therefore not be incorporated in this article.

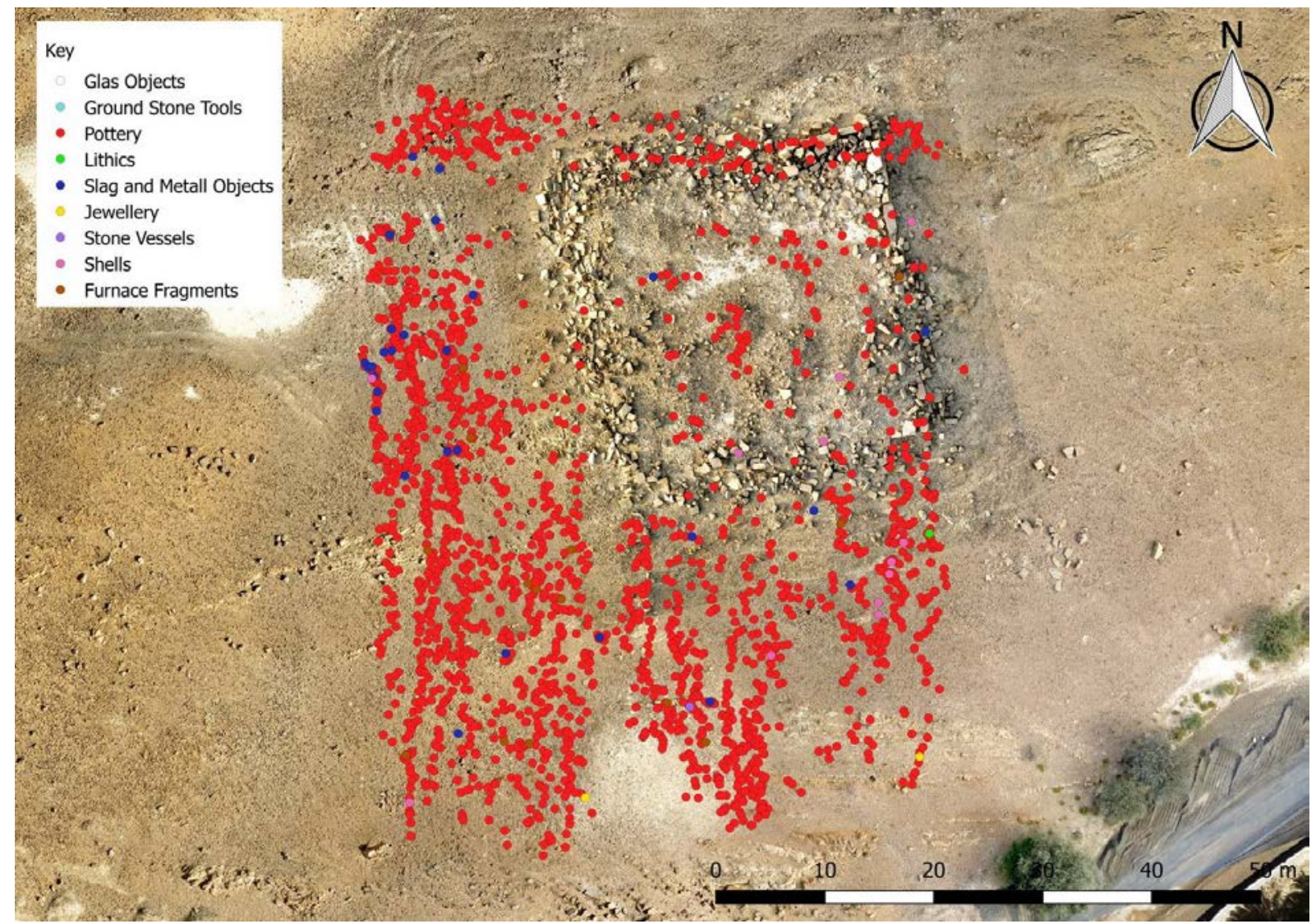

Figure 5. Building IV: Results of pedestrian survey (Map: Al-Khashbah Project).

In addition, for each of the ground stone tools, 100 to 160 photographs were taken using a Nikon D3300 camera in such a way that enabled the creation of 3D models for each object. From these, all relevant sections and views of the objects were generated (Figure 6). The 3D models replace the time-consuming hand-drawing of the objects. The models were made in two steps: first, photographs of each ground stone tool with one side facing the top of a sheet with fixed targets were taken. Secondly, another series of photographs of the other side of the ground stone tool on top of a different surface were taken. From this, it is possible to make a complete 3D model of the object true to scale using the software Agisoft Photoscan. Within this software point clouds and texturized models are generated.

\section{Ground stone tools from Al-Khashbah}

\subsection{Building I}

Different types of ground stone tools were identified among the 100 ground stone tools found during the survey and excavations at Building I. As there is no standardized typology or terminology for ground stone tools in Eastern Arabia this paper will differentiate between grinding stones, hammer stones (i.e., pounders), pestles, mortars, polishing stones (i.e., burnishers), and anvils, following mainly Wright's typology for ground stone tools for the Levant (Wright 1992), while being aware of the overall multi-functional nature of ground stone tools. 



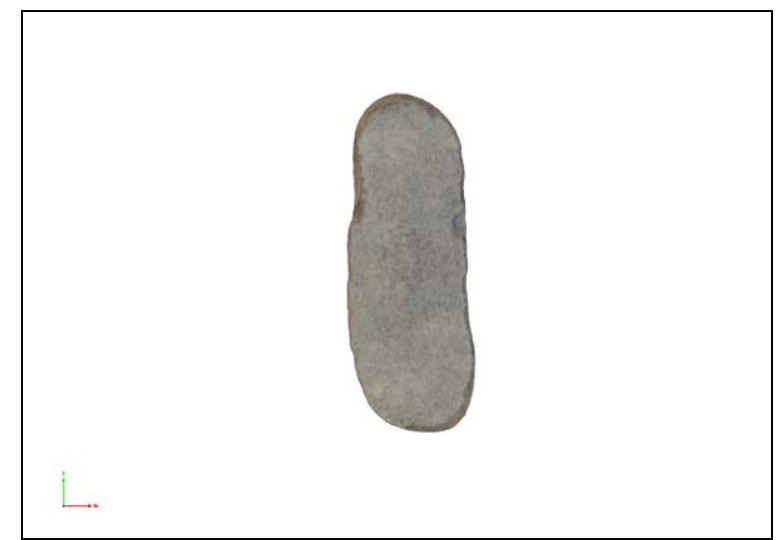

Figure 6. Examples of ground stone tool 3D models; further models are available at the Archaeoman Website (Döpper \& Schmidt 2017).

The full sized 3D image is displayed on the previous page.

At Building I, only grinding stones ( $\mathrm{n}=45)$, hammer stones $(\mathrm{n}=45)$, and polishing stones $(n=7)$ were identified. All of the grinding stones from Al-Khashbah and thus also those from Building I were found in secondary or tertiary contexts, either in the fill of the buildings, on the modern surface or incorporated in stone walls. Grinding stones and pounders clearly dominate the assemblage of Building I as each of these groups makes up $45 \%$ of all 100 ground stone tools found here (Figure 7 top). Only seven polishing stones and one possible pestle were identified in the assemblage.

There is no visible pattern in the spatial distribution of the ground stone tools found in Building I, with the exception of a slightly greater concentration in areas with stone walls, in which many may have been incorporated in secondary use (Figure 7 bottom). Furthermore, there is no visible difference in the assemblages from the survey compared to those from the excavation. Both feature the same type of objects in more or less the same quantities. This is also true for Building $\mathrm{V}$, as discussed below.

\subsubsection{Grinding stones}

The grinding stones from Building I are mostly fragmented, which makes the precise determination of their original shape and the distinction between the active upper (i.e., handstone, rubber) and passive lower (i.e., quern) grinding stone difficult. In case of more than half of the grinding stones, less than one quarter of the original tool is preserved; only two grinding stones were found complete. Therefore, upper and lower grinding stones are grouped together in this analysis. The majority of stone tools found at Al-Khashbah were assigned to this group. This allocation is supported by macroscopic use-wear analysis of the worked surfaces, which show abrasion resulting from a back and forth motion. As far as we could tell, all of the grinding stones from Building I have only one worked surface. Most of these have a concave longitudinal and concave transverse section, arguing for their identification as upper grinding stones, although convex and flat sections exist as well (Figure 8). Some of the grinding stones feature overhanging terminals. Where complete sections of the objects are preserved, measurements were taken: the length of the grinding stones varies between 158 and $365 \mathrm{~mm}$, the width between 82 and $317 \mathrm{~mm}$ and the height between 34 and $140 \mathrm{~mm}$, thus presenting a rather broad spectrum. 

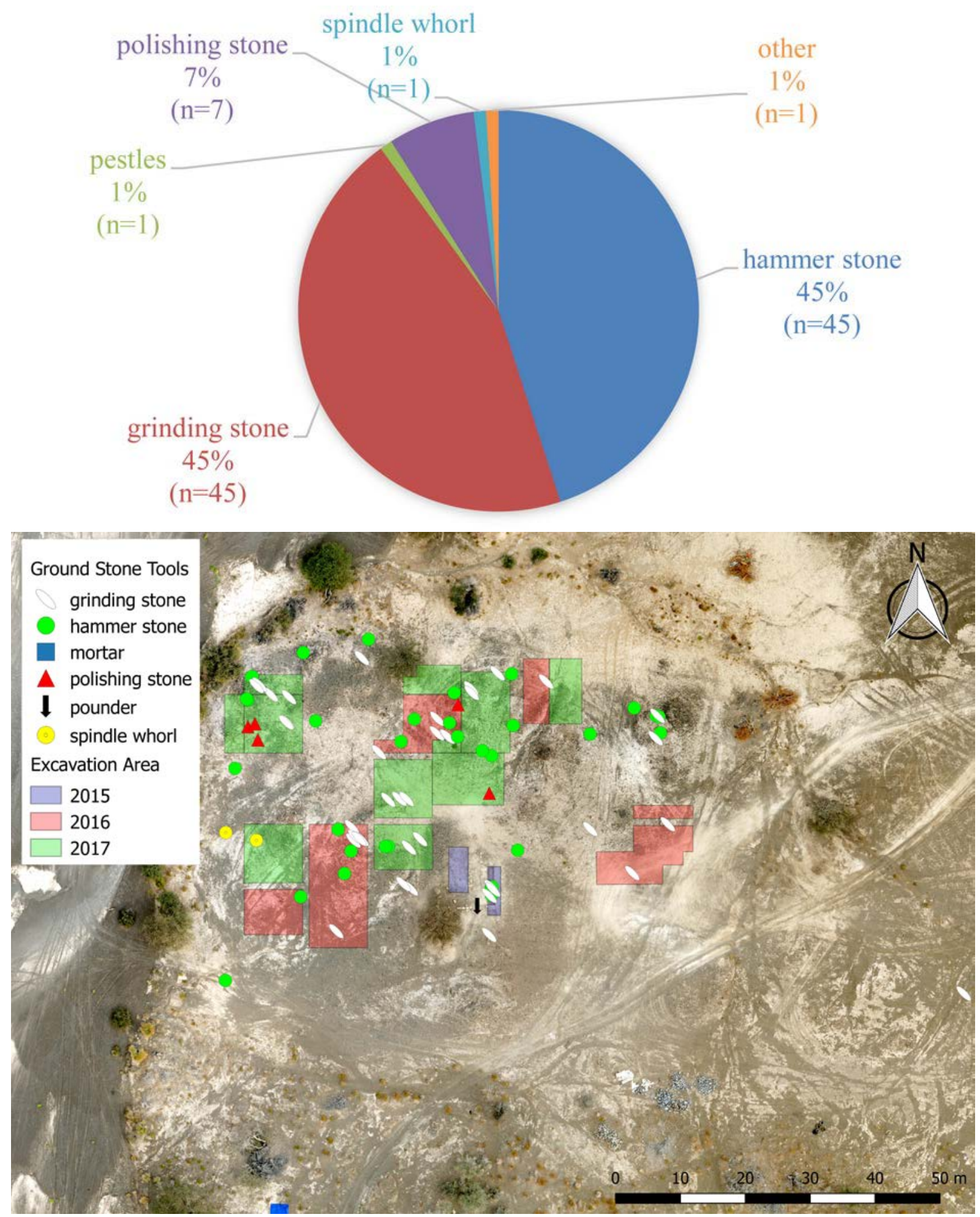

Figure 7. Quantitative (top) and spatial distribution (bottom) of ground stone tools at Building I. The extent of Building I is beyond the limits of excavation and is therefore still unclear. 


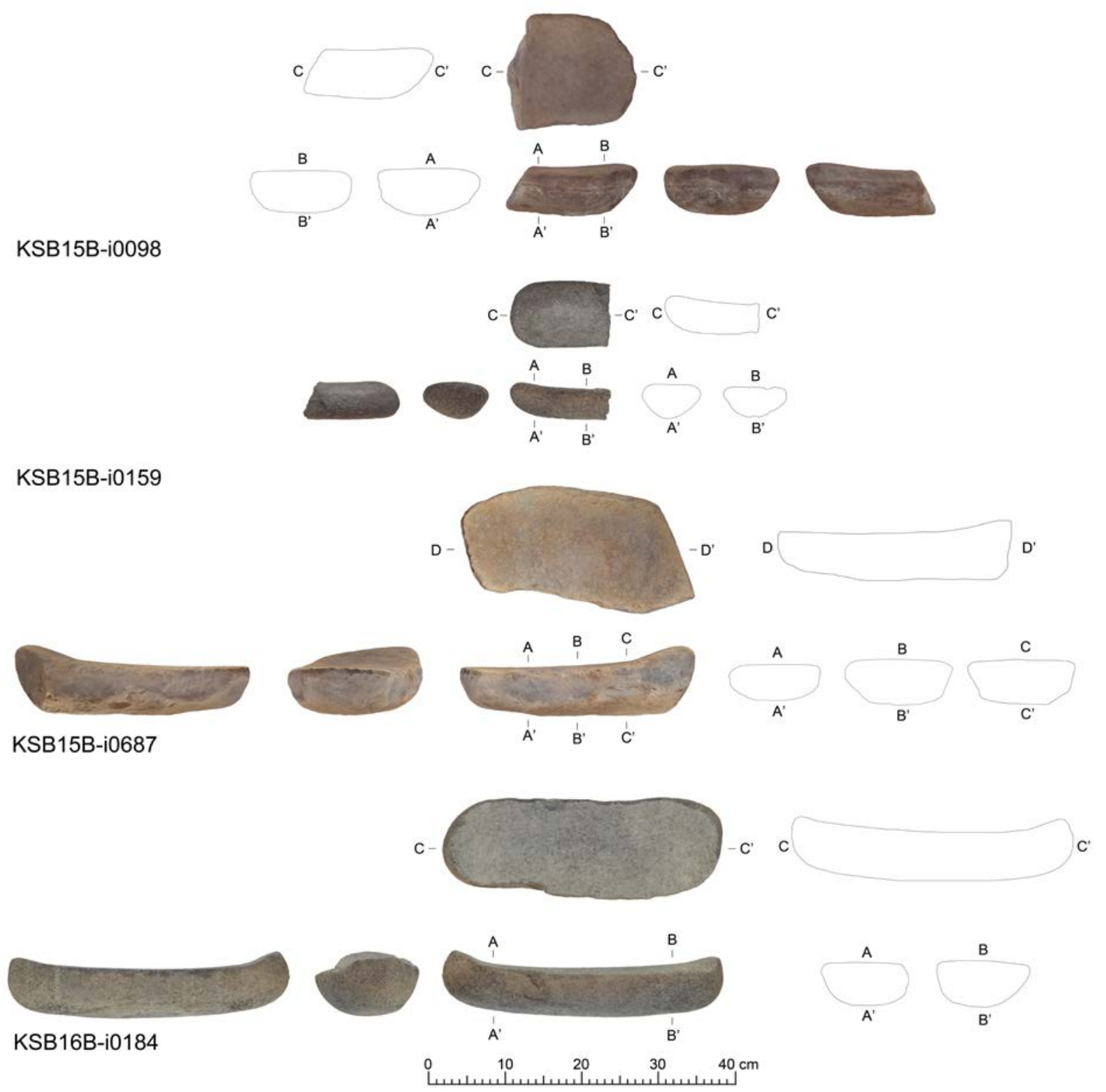

Figure 8. Grinding stones from Building I.

Two of the grinding stones from Building I (KSB16B-i0142 and KSB17B-i0286) feature worked surfaces with shallow dimples, demonstrating that they were secondarily used as worked platforms or anvils (Figure 9).

\subsubsection{Hammer stones}

The hammer stones from Building I are characterized by their small size, so that they fit into the palm of the hand. Their overall shape is cylindrical, spherical or pyramidal with a variable number of worked surfaces - anything from one to five (Figure 10). These are identified by shallow dimples, which result from downward percussive actions like pounding, hammering and crushing. Nearly all of the hammer stones were found complete. Their diameters range between 31 and $88 \mathrm{~mm}$ and their weight between 108 and $705 \mathrm{~g}$. In addition, two very small examples measuring only 25 and $36 \mathrm{~mm}$ in diameter and only 15 and $19 \mathrm{~mm}$ in height were found. They weigh 17 and 28 g respectively. 
One small pestle or oblong hammer-stone made of black stone was identified. It measures $53 \mathrm{~mm}$ in length with a $31 \mathrm{~mm}$ diameter and has a weight of $82.7 \mathrm{~g}$. At its distal end shallow dimples are visible.

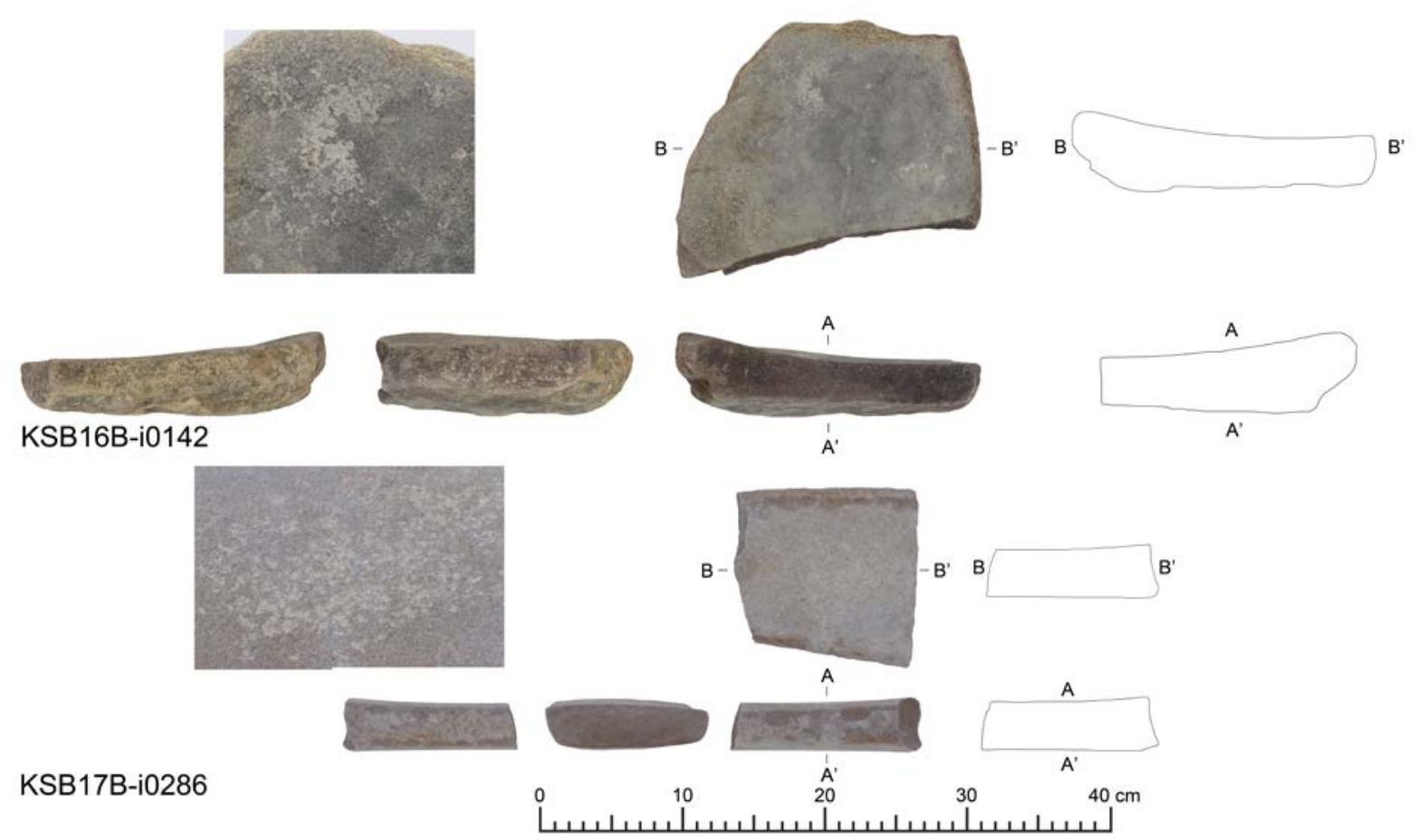

Figure 9. Grinding stones KSB16B-i0142 and KSB17B-i0286 with shallow dimples on the worked surface.

\subsubsection{Polishing stones}

As they are modified solely through use, the seven polishing stones from Building I are identified by a highly polished, smooth and often shiny worked surface (Figure 11). They can have very different shapes: some of them are much larger and heavier, and thus stationary, others are smaller and lighter and could have been carried around easily.

\subsection{Building V}

The ground stone tool assemblage from Building $\mathrm{V}$ are made up of more or less the same types as those from Building I, but with fewer objects in total. Only 32 ground stone tools were found here. Grinding stones and hammer stones again clearly dominate the assemblage, each comprising 40 to $50 \%$ of all ground stone tools (Figure 12 top). In addition, one polishing stone and two boulder mortars were found. The spatial distribution of the ground stone tools reveals no distinct patterning (Figure 12 bottom).

\subsubsection{Grinding stones}

Similar to the sixteen grinding stones from Building I, most from Building V were found fragmented; in half of them, not more than $25 \%$ is preserved. No complete examples were found. Comparable to the grinding stones from Building I, they all feature only one worked surface and have predominantly concave longitudinal and convex transverse sections (Figure 13). As far as preserved, the grinding stones have a width between 124 and $245 \mathrm{~mm}$ and a height between 39 to $90 \mathrm{~mm}$. No complete length could be determined. 


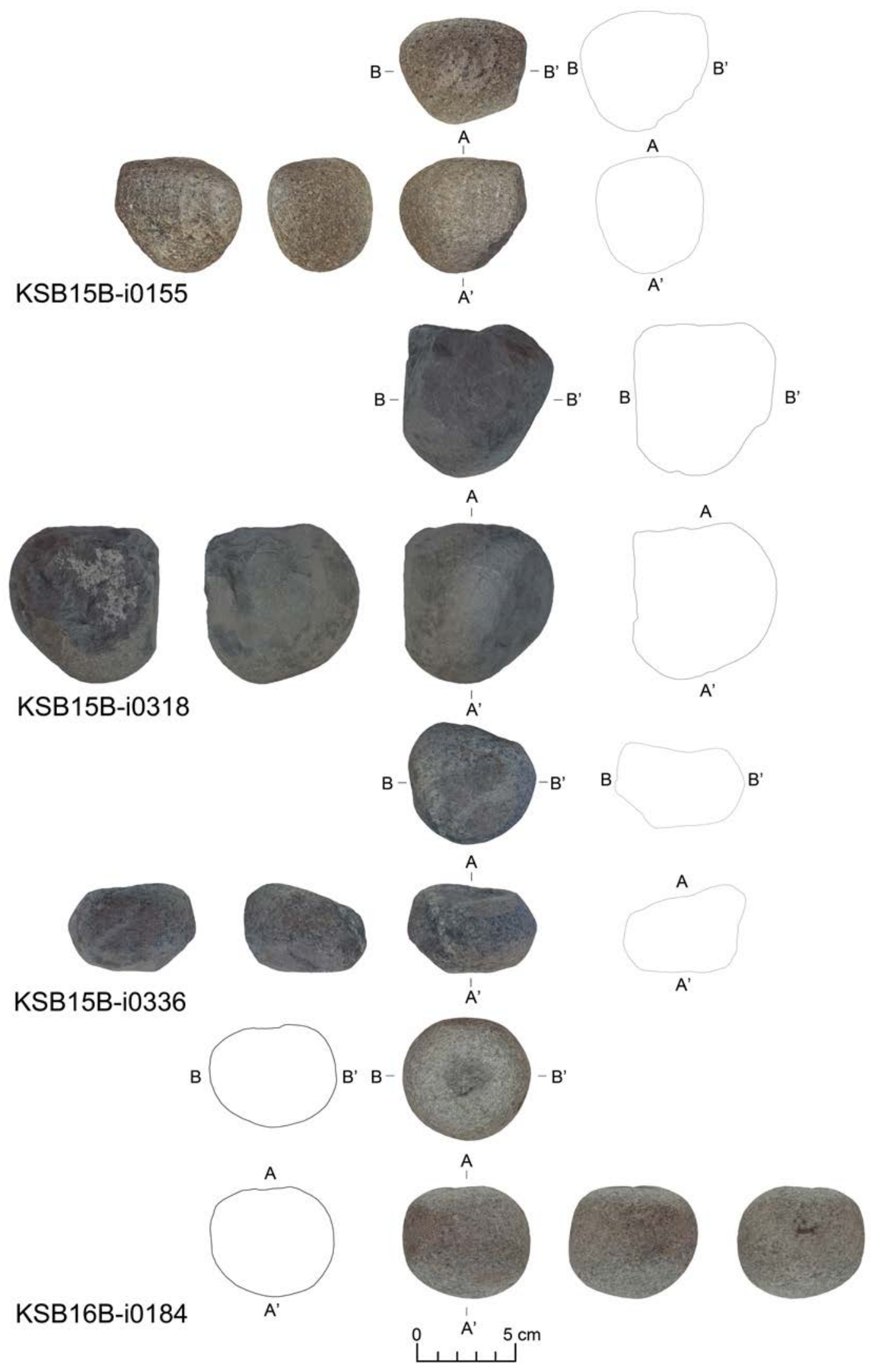

Figure 10. Hammer stones from Building I. 


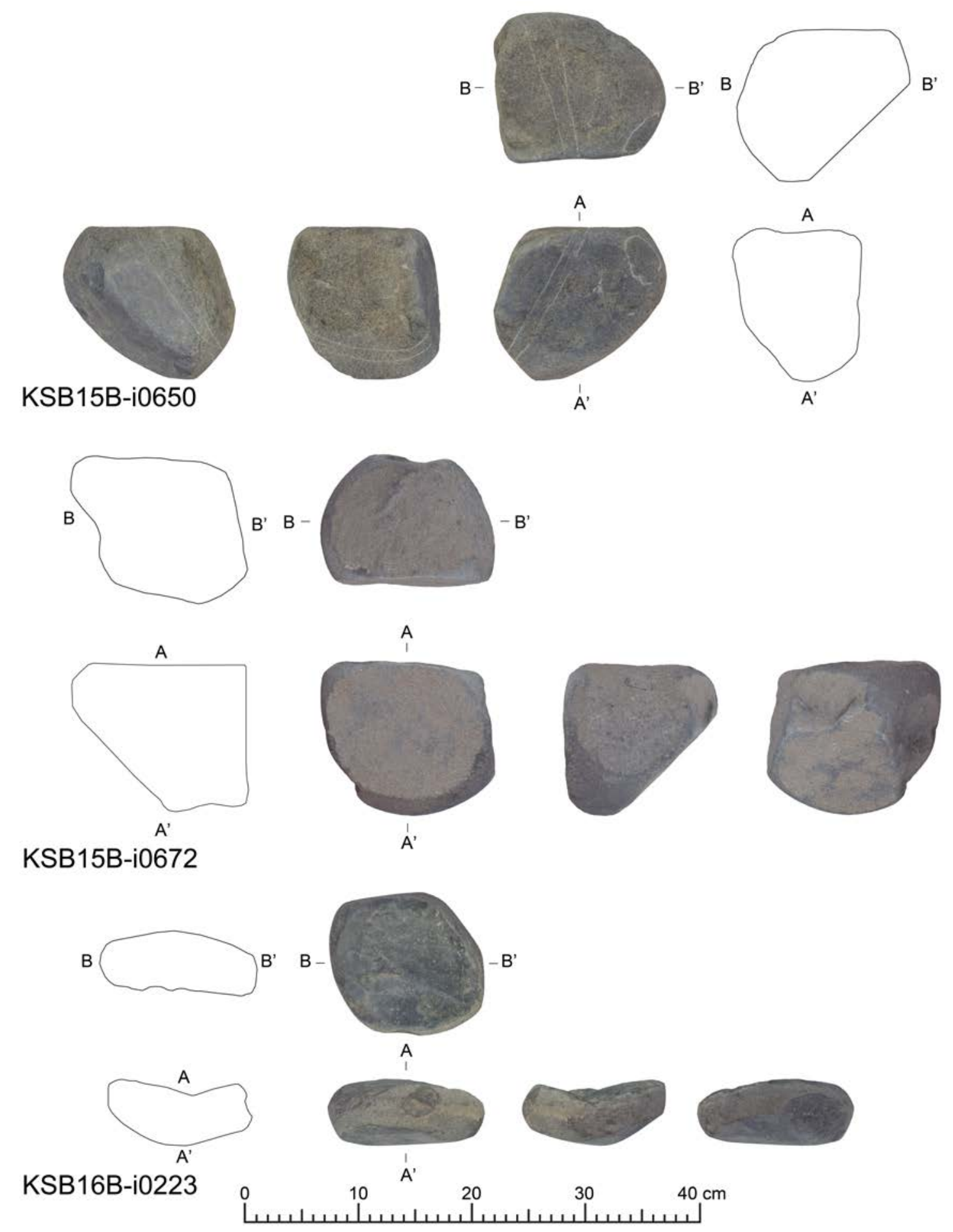

Figure 11. Polishing stones from Building I.

\subsubsection{Hammer stones}

The twelve hammer stones from Building $\mathrm{V}$ are also very similar to those of Building I. They are cylindrical or roughly spherical in shape, fit well into the palm of the hand and feature variable numbers of worked surfaces, whose character differs by the degree of intensity and force by which they were worked (Figure 14). Nearly all of them were found complete with diameters from 40 to $81 \mathrm{~mm}$ and a weight between 186 to $530 \mathrm{~g}$. Thus, they are on average slightly heavier than those from Building I. 

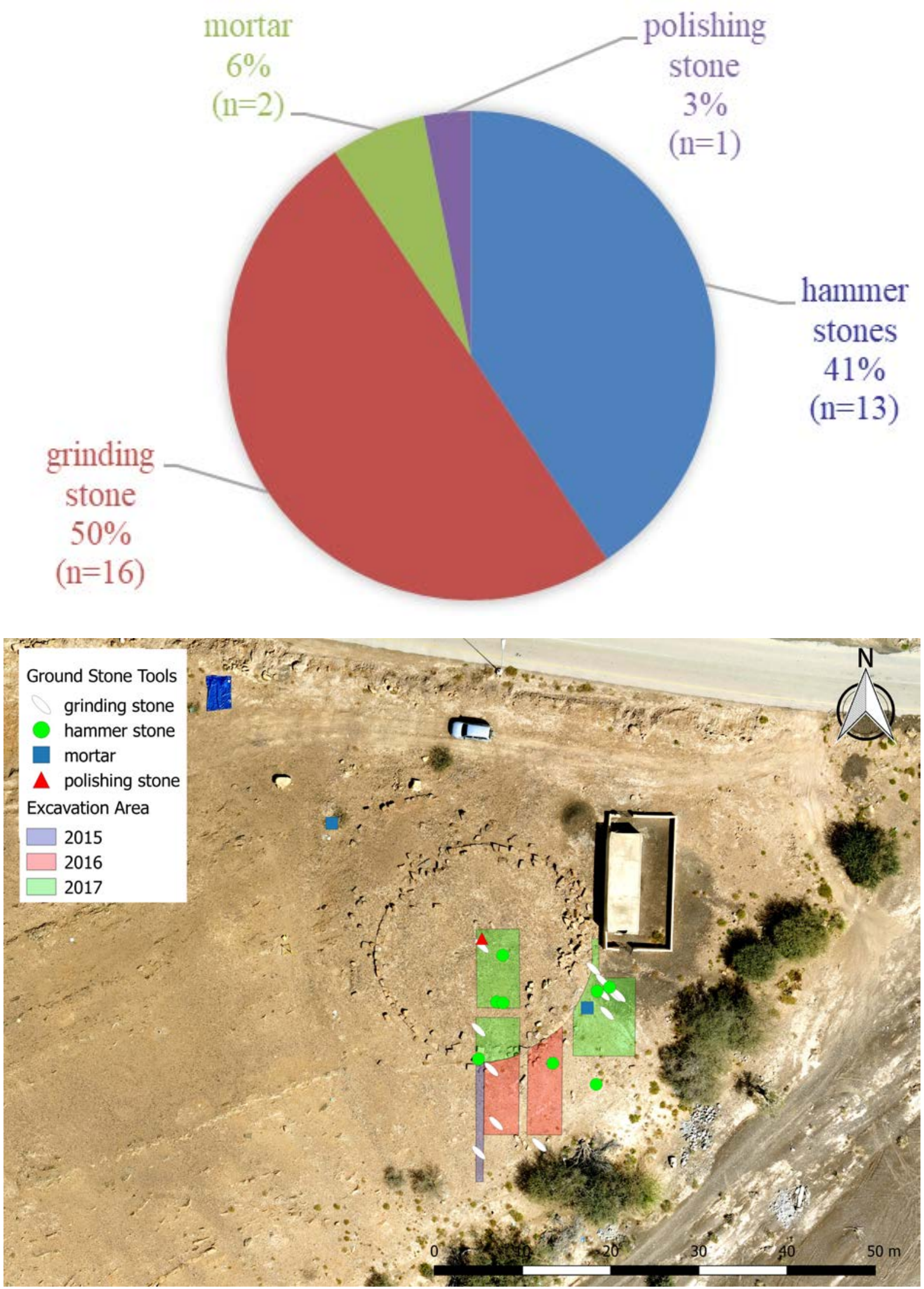

Figure 12. Quantitative (top) and spatial distribution (bottom) of ground stone tools at Building V. 


\subsubsection{Mortars}

Interesting are the two boulder mortars, one fragmented and the other one complete. The fragment shows a $9 \mathrm{~cm}$ deep depression. No other modification of the stone except that of the use-surface is visible. The other mortar was found cut into one of the huge stone blocks measuring $180 \times 80 \times 50 \mathrm{~cm}$, which was used in the external wall of the tower (Figure 15). This is probably an indicator that this mortar was only added after the building fell out of use. At the top, the depression of this mortar has a diameter of $25 \mathrm{~cm}$, from which it narrows down to a diameter of approximately $5 \mathrm{~cm}$ at the bottom. It is $20 \mathrm{~cm}$ deep.

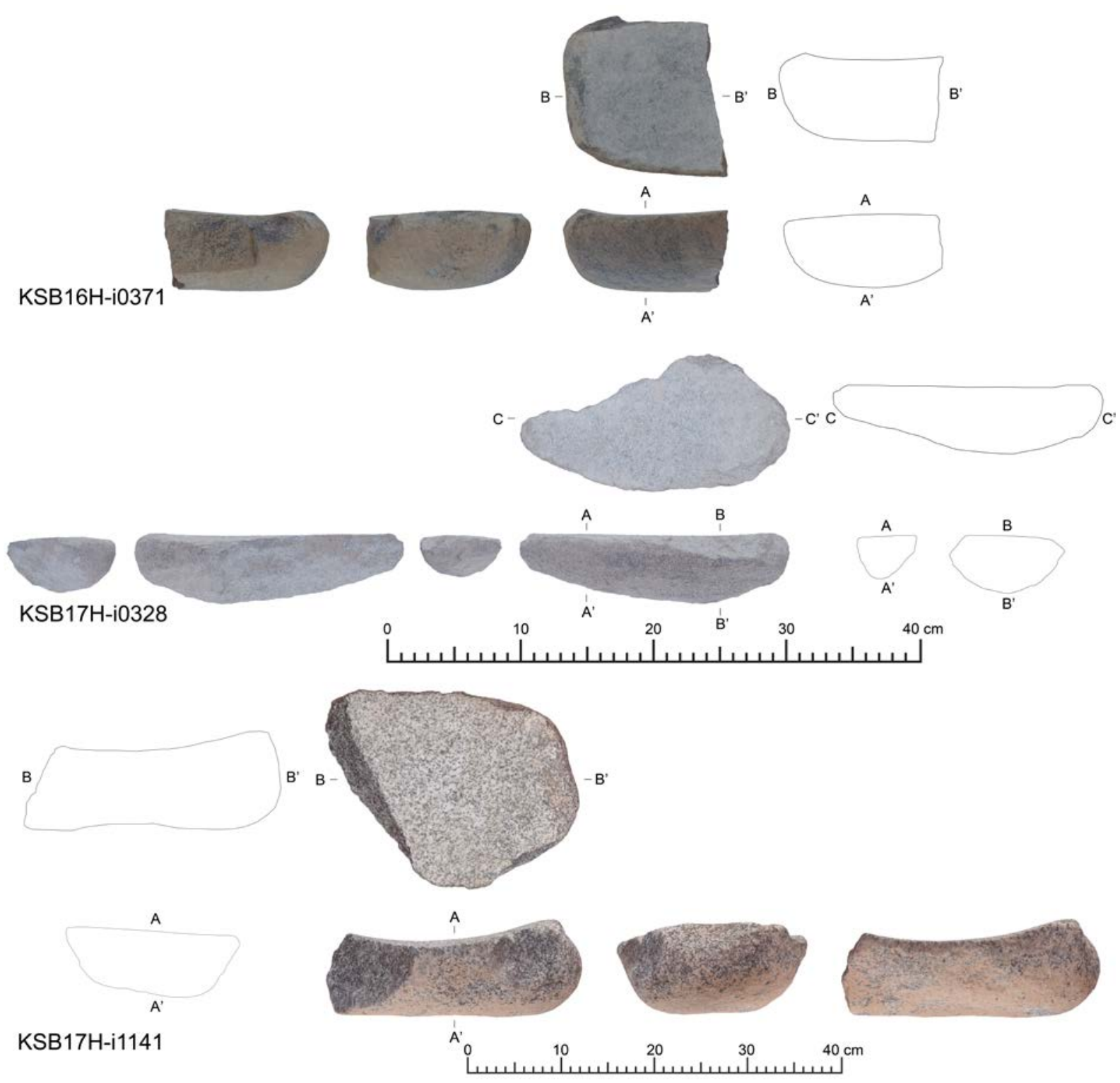

Figure 13. Grinding stones from Building V.

\subsection{Building IV}

Building IV featured very few ground stone tools. No grinding stones or hammer stones were found during the pedestrian surface survey and no excavations have been conducted here. There are, however, two mortars and two large stones with a number of cup-marks or dimples that can be interpreted as anvils. The two mortars were found cut into collapsed 
stones from the walls of Building IV, clearly shifted into a tertiary position as they were upside down.

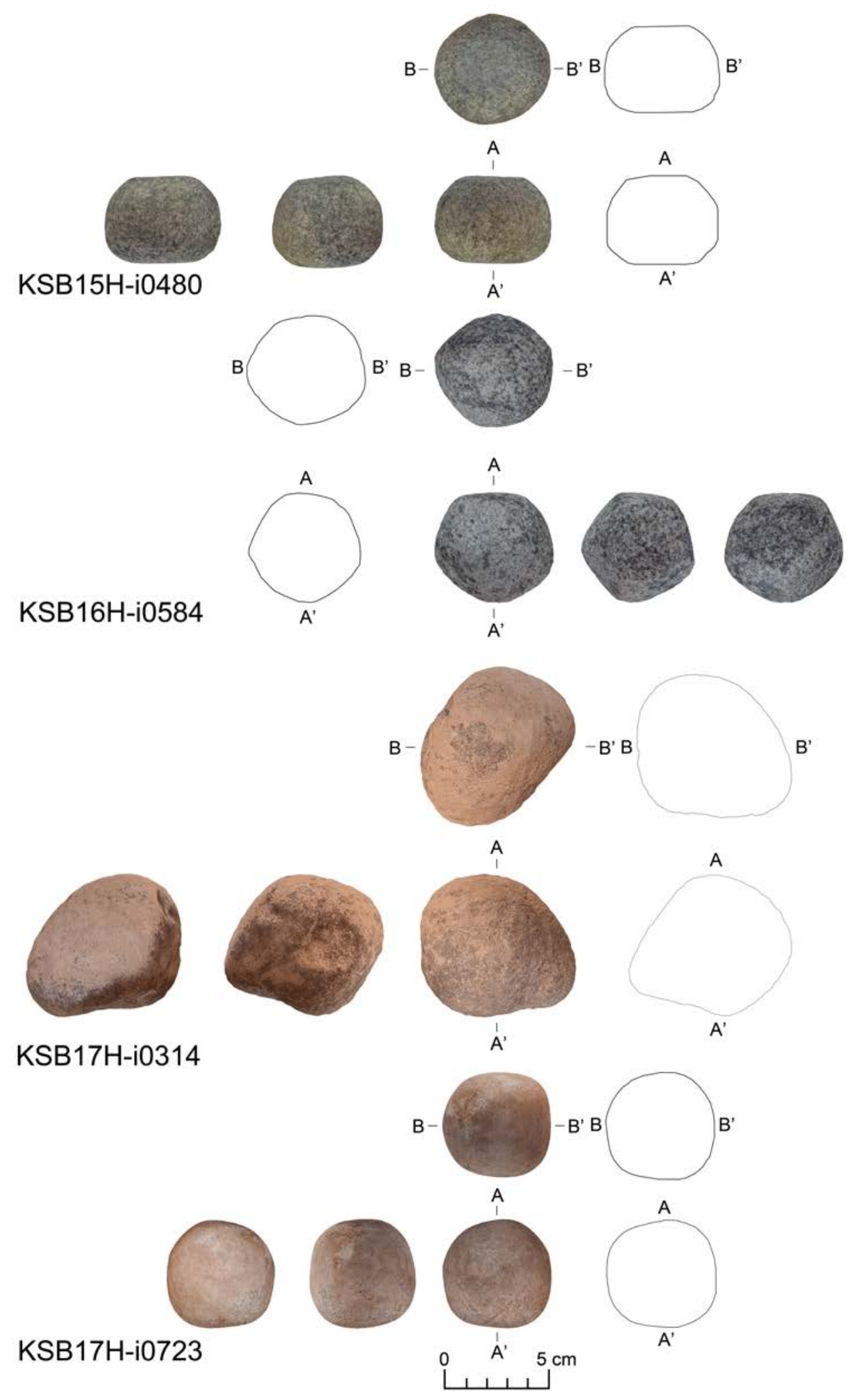

Figure 14. Hammer stones from Building V. 


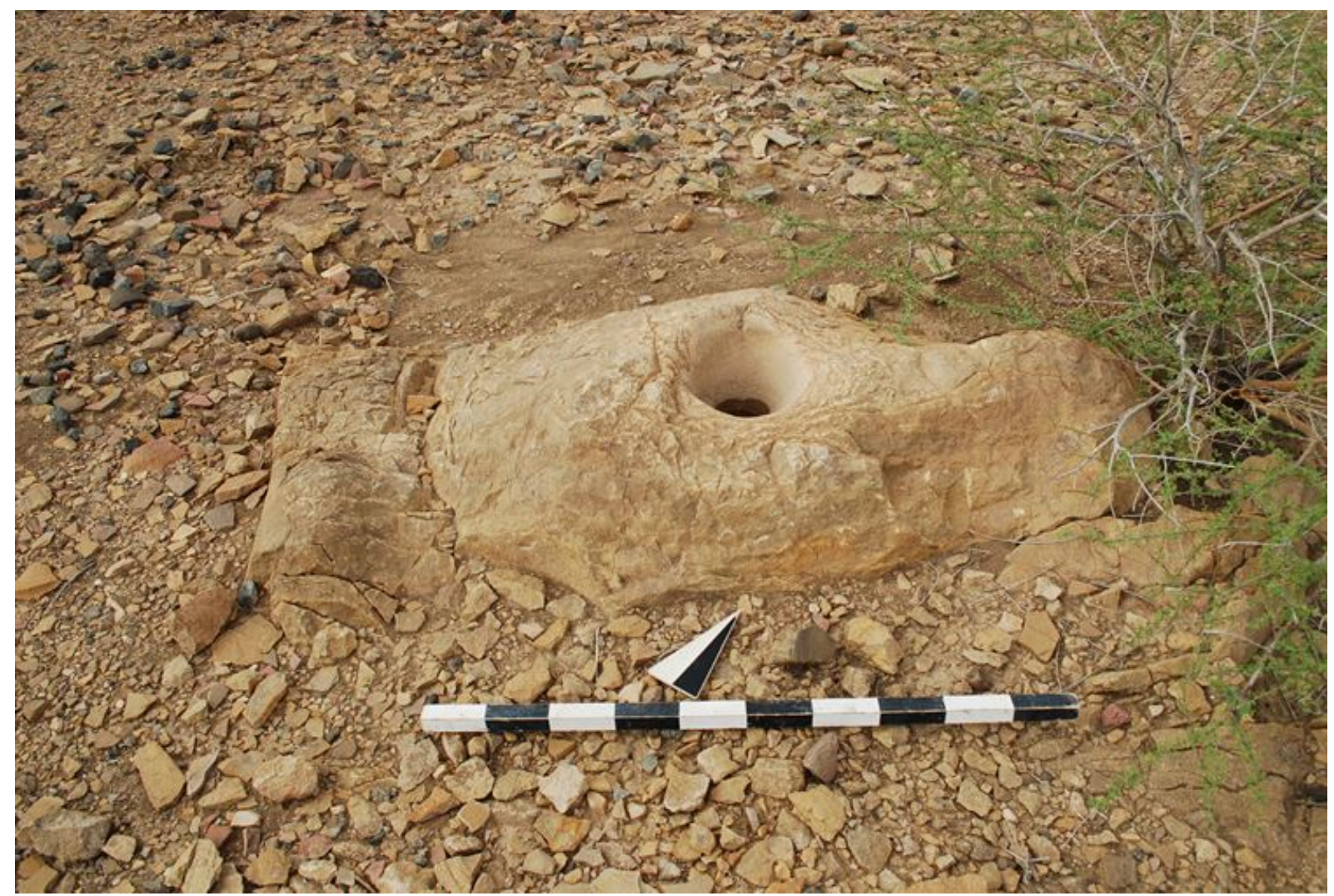

Figure 15. Mortar in the external wall of Building V.

The two large stones with multiple small cup-marks were found on two stones collapsed from the external walls of Building IV and thus dating later than the original use of the building in the $3^{\text {rd }}$ millennium BCE (Figure 16). Possibly they are related to the petroglyphs described above. They could have functioned as platform used in conjunction with percussion tools. However, it has also been suggested that they are not anvils, but represent a gaming board for a game comparable to the Royal Game of Ur (Fossati 2015 (unpublished)).

\section{Ground stone assemblages from other Early Bronze Age sites in Eastern Arabia}

Comparing the ground stone tool assemblage from the copper production sites of $\mathrm{Al}$ Khashbah with other $3^{\text {rd }}$ millennium BCE sites in Eastern Arabia is challenging as very few assemblages have been published. A good number of $3^{\text {rd }}$ millennium BCE ground stone tools from sites in Eastern Arabia were found in tombs, among them those of the necropolis of Bat (Böhme \& Ali Al-Sabri 2011: 148) and Umm an-Nar Island (Frifelt 1991: 104-111). In the Near East and Arabia in general, the presence of ground stone tools in tombs has also been noticed and interpreted as remains of feasting, in which they were used for food preparation (Ebeling 2002: 149), or other burial rituals (Rosenberg \& Nadel 2014), the buried individual's personal property (Ebeling 2002: 150) or status objects (Rosenberg \& Nadel 2014) that accompanied her or him into the netherworld, or "implements bearing significant symbolic meanings pertaining to the production of food and the transformation of substances from one state to another” (Rosenberg \& Nadel 2014: 788). 

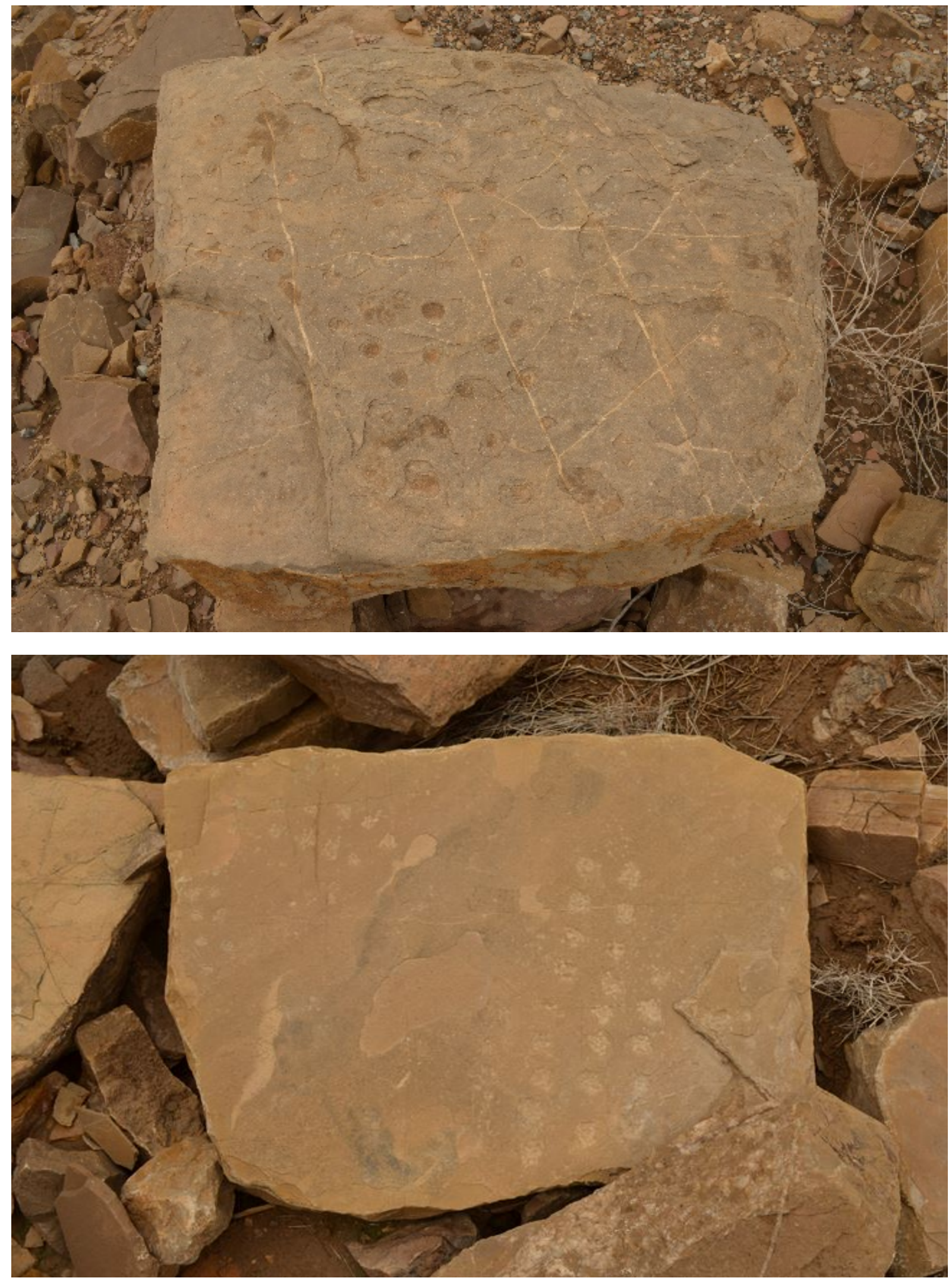

Figure 16. Large stones with multiple small cup-marks from Building IV.

$3^{\text {rd }}$ millennium BCE ground stone assemblages from non-funerary contexts in Eastern Arabia are known amongst others from the settlements of Umm an-Nar Island (Frifelt 1995), Tell Abraq (Potts 1991: 30-32), Hili (Cleuziou 1989: 73), Maysar (Weisgerber 1980; 1981), 
and the towers at Bat (Costa 2016). At Bat, 81.9\% of the assemblage are grinding stones (Costa 2016: 254). Many of them seem to have been reused as building materials in the stone walls of the towers (Costa 2016: 255), although a large variety of functions for the ground stone tools have been suggested, including processing edible substances such as plant foods as well as for copper ore and slag processing (Costa 2016: 256). For the coastal site of Tell Abraq, hammer stones found there are interpreted as mainly being used for cracking and opening shells (Potts 1991: 99). At Bat Tomb 401, the excavators could identify hammer stones found on the surface surrounding the tomb that were used in the trimming of the façade stones for the tomb (Böhme \& Ali Al-Sabri 2011: 119).

A large number of ground stone tools were found at Maysar, many of which were in an ancient well (Weisgerber 1980: 83 Abb. 35-36, 85). They include upper and lower grinding stones, hammer stones, as well as whetstones. In other parts of the settlement large stones that might have been used as anvils were identified, some of them in association with slag, copper fragments and charcoal and often accompanied by hammer stones (Weisgerber 1980: 88; 1981: 192-193, 195 Abb. 19). Maysar is clearly a site of intensive copper working dating to the end of the $3^{\text {rd }}$ millennium BCE evidenced by the large quantities of slag, furnace fragments and other copper production waste, as well as copper ingots. Concerning the grinding stones, which are manufactured from gabbro, the excavator Gerd Weisgerber states that as none of them had been found in an undisturbed context, it is not clear whether they were used for grinding cereals or breaking up copper (Weisgerber 1981: 197). There is evidence that the ground stone tools from Maysar were fashioned with the help of copper tools such as chisels (Weisgerber 1981: 197, 198 Abb. 22).

Several grinding stones are reported from the settlement of Umm an-Nar Island, as well as one mortar and a few runners. They are thought to have predominantly been used for grinding grain (Frifelt 1995: 200-204). The large number of hammer stones found on Umm an-Nar Island, especially in the workshop quarter, are interpreted as being used in copper production (Frifelt 1995: 209-210). By comparing them to those from Al-Maysar, Frifelt especially regards those with large central depressions as being used in crushing copper ore. At Zahra and Wadi Fizh, two $3^{\text {rd }}$ millennium BCE settlements with clear evidence of copper working on the Batinah coast of Oman, several hammer stones were also found (Costa \& Wilkinson 1987: 97-98, 105; Weisgerber 1987: 148).

\section{Discussion and comparisons}

When comparing the ground stone tool assemblages from the different buildings at $\mathrm{Al}$ Khashbah, the many similarities between Building I and Building V, as well as the striking difference between those two buildings and Building IV, i.e., the general lack of ground stone tools, becomes clearly visible (Figure 17). At Building II, which is another monumental stone tower investigated by the University of Tübingen at Al-Khashbah (Figure 2), no ground stone tools were found as well. Building $\mathrm{I}$ and Building $\mathrm{V}$ date to the very beginning of the $3^{\text {rd }}$ millennium BCE, in the Hafit period, while Building II and Building IV date to the second half of the $3^{\text {rd }}$ millennium BCE, which is the Umm an-Nar period. The more striking difference beyond this chronological division is, however, the presence of waste products from copper production. At Building I and Building V, large quantities of slag, furnace fragments and prills were found, all indicating intensive and large-scale copper production. Building II and Building IV have no or nearly no evidence of metallurgy. Therefore, it is most plausible to see the ground stone tools as used within the operational procedures of copper processing as it has been demonstrated for other metal-processing sites. 


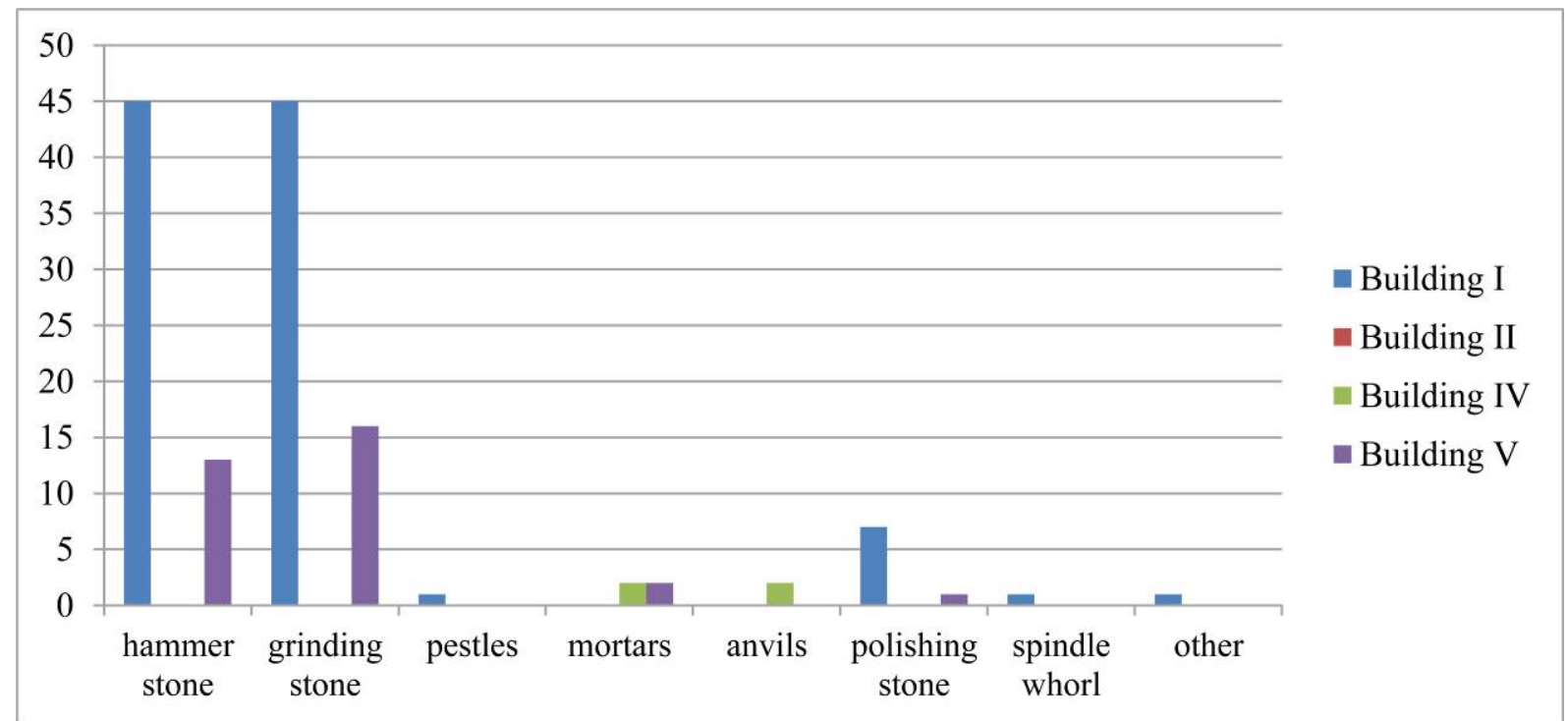

Figure 17: Comparison of the ground stone tool assemblages from Building I, II, IV, and V.

It has been suggested by various scholars that not just pounders and anvils, but also grinding stones and mortars, played a role in pounding, grinding and crushing slag and copper ore as part of the beneficiation process or in order to free all entrapped copper prills that were not separated from the slag during the smelting process (Doumas 2011: 166; Greener \& BenYosef 2016: 211-216; Levy et al. 2016: 333; Vardi et al. 2008: 18; Webb 2015: 31). The hardness of the raw material, ratio of tools involved in percussive versus abrasive tasks, the reuse of any available heavy stone for percussive or crushing activities, and the lack of tribochemical wear on grinding equipment has been claimed to be a hallmark for differentiation between industrial ground stone assemblages associated with metallurgy and domestic assemblages (Greener \& Ben-Yosef 2016: 210; Levy et al. 2016: 332; Webb 2015: 34). Ethnographic parallels from modern India demonstrate the crushing of copper production waste prior to re-smelting with a range of different pounding and grinding tools (Levy et al. 2008: 83-95). Therefore, the connection between the grinding stone assemblages from Building $\mathrm{I}$ and Building $\mathrm{V}$ at Al-Khashbah with the metal production identified by the different waste products at both sites is highly plausible. For Building I, it should be pointed out that it is also very plausible that at least some of the percussive tools found were used for flint knapping and not copper processing. Large quantities of flint debris, cores and debitage were found at the site.

In addition, the high fragmentation of grinding stones present in the assemblages of Building I and Building $\mathrm{V}$ is interpreted, as at other metal working sites, as an indicator for their reuse as heavy crushing tools (Webb 2015: 24). Other Near Eastern sites such as Çatalhöyük, however, could demonstrate that grinding stones were deliberately broken, probably as part of house abandonment rituals (see also Adams 2008; Wright 2013: 380). Further, a large number of ground stone tools at Al-Khashbah were found in secondary or tertiary contexts, often reused in stone walls. Although it has been claimed that in those instances ground stone tools are not to be merely perceived as building materials but have symbolic significance related to their social and economic worth (Rosenberg 2013), such find contexts make the functional interpretation of a ground stone assemblage difficult and limit our possibilities for understanding the type of activities taking place in the towers.

Comparing the ground stone tool assemblage from Al-Khashbah with contemporaneous sites from Eastern Arabia is difficult as few assemblages have been published. Nevertheless, the overall variety of types seems to be rather homogeneous and at least some of the sites like 
Umm an-Nar Island and Maysar provide clear evidence for ground stone tools used in copper processing.

\section{Conclusions}

The ground stone tool assemblages from the $3^{\text {rd }}$ millennium BCE site of Al-Khashbah are associated with monumental stone or mud-brick buildings, the so-called towers of the early $3^{\text {rd }}$ millennium BCE, i.e., the Hafit period. Plenty other evidence for copper processing is present in these towers, and nearly completely absent from the towers of the second half of the $3^{\text {rd }}$ millennium BCE, the Umm an-Nar period. This indicates a change in the activities taking place at the towers from one period to the other. While the use of ground stone tools in metal processing activities has been clearly demonstrated at sites in other regions of the world, comparisons of the ground stone tool assemblage from Al-Khashbah with other contemporaneous sites in Eastern Arabia are less informative. Only some sites like Umm anNar Island and Maysar provide evidence for ground stone tools used in copper processing activities, while at many other sites they were found in tombs. This situation is however, more likely due to the current state of research and publication rather than a real absence of ground stone tools. Nevertheless, the ground stone tools assemblage from Al-Khashbah provides a valuable insight into economic changes at the site.

\section{Acknowledgements}

This article was written when the author was a Feodor Lynen Research Fellow at Frankfurt University. The archaeological investigations at Al-Khashbah were conducted in cooperation with the Ministry of Heritage and Culture of the Sultanate of Oman and made possible through the generous financial support of the German Research Foundation. The author would like to thank Philippe Kluge and Martin Offermann for the generation of the 3D models of the ground stone tools and Leonie Pathé for producing the illustrations of the ground stone tools from these models.

\section{References}

Adams, J.L. 2008, Beyond the Broken. In: New Approaches to Old Stones. Recent Studies of Ground Stone Artifacts (Rowan, Y.M. \& Ebeling, J.R., Eds.), Equinox Publishing, London: p. 213-229.

Al-Jahwari, N.S. 2013, The Early Bronze Age Funerary Archaeological Landscape of Western Ja'alan: Results of Three Seasons of Investigation. Arabian Archaeology and Epigraphy, 24(2): 151-173. doi:10.1111/aae.12014

Al-Jahwari, N.S. \& Kennet, D. 2010, Umm an-Nar Settlement in the Wādī Andam (Sultanate of Oman). Proceedings of the Seminar for Arabian Studies, 40: 201-212.

Böhme, M. \& Ali Al-Sabri, B. 2011, Umm an-Nar burial 401 at Bat, Oman: architecture and finds. Arabian Archaeology and Epigraphy, 22: 113-154.

Cleuziou, S. 1989, Excavations at Hili 8: A Preliminary Report on the 4th to 7th Campaigns. Archaeology in the United Arab Emirates, 5: 61-87.

Cleuziou, S. 2009, Extracting Wealth from a Land of Starvation by Creating Social Complexity: A Dialogue between Archaeology and Climate? Comptes Rendus Geoscience, 341: 726-738. doi:10.1016/j.crte.2009.06.005 
Cleuziou, S. \& Tosi, M. 2007, In the Shadow of the Ancestors. The Prehistoric Foundations of the Early Arabian Civilization in Oman. Ministry of Heritage \& Culture, Sultanate of Oman, Muscat, 334 p.

Costa, P.M. \& Wilkinson, T.J. 1987, The Hinterland of Sohar. Archaeological Surveys and Excavations within the Region of an Omani Seafaring City. Journal of Oman Studies, 9: $1-238$.

Costa, T. 2016, Preliminary Report on Ground Stone Artifacts from Bat. In: The Bronze Age Towers at Bat, Sultanate of Oman. Research by the Bat Archaeological Project, 200712 (Thornton, C., Cable, C. \& Possehl, G.L., Eds.), University of Pennsylvania Press, Philadelphia: p. 239-257.

Döpper, S. \& Schmidt, C., 2017, Al-Khashbah 3D-Models Finds. Retrieved 13 January 2019. URL: https://www.archaeoman.de/en/al-khashbah-3d-modelle-funde/

Doumas, C.G. 2011, Searching for the Early Bronze Age Aegean Metallurgist's Toolkit. In: Metallurgy: Understanding How, Learning Why. Studies in Honor of James D. Muhly (Betancourt, P.P. \& Ferrence, S., Eds.), INSTAP Academic Press, Philadelphia: p. 165179.

Ebeling, J.R. 2002, Why are Ground Stone Tools Found in Middle and Late Bronze Age Burials? Near Eastern Archaeology, 65(2): 149-151. doi:10.2307/3210876

Fossati, A.E. 2015 (unpublished), Rock Art Mission Report. (Kasr al-Sleme) - Khadal, Safri 1, Khasbah, and Rock Art Sites in Adh Dhahirah Region (Ibri, Yanqul and Dank) (15 November - 9 December 2015). Catholic University Milan, Dept. of History, Archaeology and History of Art

Frifelt, K. 1976, Evidence of a Third Millennium BC Town in Oman. The Journal of Oman Studies, 2: 57-67.

Frifelt, K. 1989, Third Millennium Irrigation and Oasis Culture in Oman. In: Old Problems and New Perspectives in the Archaeology of South Asia: p. 105-113.

Frifelt, K. 1991, The Island of Umm An-Nar. Vol. 1: Third Millenium Graves. Aarhus University Press, Aarhus, 188 p.

Frifelt, K. 1995, The Island of Umm an-Nar 2: The Third Millennium Settlement. The Carlsberg Foundation's Gulf Project. Aarhus University Press, Aarhus, 260 p.

Frifelt, K. 2002, Bat, a Center in Third Millennium Oman. In: Essays on the Late Prehistory of the Arabian Peninsula (Cleuziou, S., Tosi, M. \& Zarins, J., Eds.), Serie orientale Roma Vol. XCIII, Roma: p. 101-110.

Greener, A. \& Ben-Yosef, E. 2016, The Ground Stone Assemblage of a Metal Workers Community: An Unexplored Dimension of Iron Age Copper Production at Timna. Journal of Lithic Studies, 3(3): 191-220. doi:10.2218/jls.v3i3.1678

Hastings, A., Humphries, J.H. \& Meadow, R.H. 1976, Oman in the Third Millennium BCE. Journal of Oman Studies, 1: 9-55.

Levy, T.E., Bettilyon, M. \& Burton, M.M. 2016, The Iron Age Copper Industrial Complex: A Preliminary Study of the Role of Ground Stone Tools at Khirbat en-Nahas, Jordan. Journal of Lithic Studies, 3(3): 313-335. doi:10.2218/jls.v3i3.1648 
Levy, T.E., Levy, A., Radhakrishna Sthapathy, D., Srikanda Sthapathy, D. \& Swaminatha Sthapathy, D. 2008, Masters of Fire: Hereditary Bronze Casters of South India. Veröffentlichungen aus dem Deutschen Bergbau-Museum Bochum Vol. 162. Deutsches Bergbau-Museum, Bochum, 144 p.

Orchard, J. \& Orchard, J. 2002, The Work of the Al Hajar Project in Oman. Journal of Oman Studies, 12: 227-234.

Potts, D.T. 1991, Further Excavations at Tell Abraq. The 1990 Season, Munksgaard, Copenhagen, $154 \mathrm{p}$.

Reade, J. 2000, Sacred Places in Ancient Oman. Journal of Oman Studies, 11: 133-138.

Rosenberg, D. 2013, Not 'Just Another Brick in the Wall?’ The Symbolism of Groundstone Tools in Natufian and Early Neolithic Southern Levantine Constructions. Cambridge Archaeological Journal 23: 185-201. doi:10.1017/S095977431300022X

Rosenberg, D. \& Nadel, D. 2014, The Sounds of Pounding: Boulder Mortars and their Significance to Natufian Burial Customs. Current Anthropology, 55(6): 784-812. doi:10.1086/679287

Schmidt, C. \& Döpper, S. 2017a, The Development of Complexity at Third-Millennium BC Al-Khashbah, Sultanate of Oman: Results of the First Two Seasons, 2015 and 2016. Proceedings of the Seminar for Arabian Studies, 47: 215-226.

Schmidt, C. \& Döpper, S. 2017b, Die Entstehung komplexer Siedlungen im nördlichen InnerOman im 3. Jahrtausend v. Chr.: Bericht über die Ausgrabungen 2015 und 2016 in AlKhashbah. Mitteilungen der Deutschen Orient-Gesellschaft, 149: 121-158. (in German) ("The Development of Complex Settlements in Northern Inner Oman in the 3rd Millennium BC: Report on the 2015 and 2016 Excavation Seasons in Al-Khashbah")

Vardi, J., Shilstein, S., Shalev, S. \& Yekutieli, Y. 2008, The Early Bronze Age IV Chipped and Ground Stone Assemblage of 'En Yahav and its Relation to Copper Smelting Activities. Journal of the Israel Prehistoric Society, 38: 1-20.

Webb, J.M. 2015, Identifying Stone Tools Used in Mining, Smelting, and Casting in Middle Bronze Age Cyprus. Journal of Field Archaeology, 40(1): 22-36. doi:10.1179/0093469014Z.000000000108

Weisgerber, G. 1980, "...und Kupfer in Oman" - Das Oman-Projekt des Deutschen BergbauMuseums. Der Anschnitt. Mitteilungsblatt der Vereinigung der Freunde von Kunst und Kultur im Bergbau 32(2-3): 62-110. (in German) (“"... and Copper in Oman" - The Oman-Project of the German Mining Museum”)

Weisgerber, G. 1981, Mehr als Kupfer in Oman. Ergebnisse der Expedition 1981. Der Anschnitt. Mitteilungsblatt der Vereinigung der Freunde von Kunst und Kultur im Bergbau 33(5-6): 174-263. (in German) ("More than Copper in Oman. Results of the 1981 Expedition")

Weisgerber, G. 1987, Archaeological Evidence of Copper Exploitation at 'Arja. Journal of Oman Studies, 9: 145-172.

Wright, K.I. 1992, Ground Stone Assemblage Variations and Subsistence Strategies in the Levant, 22,000 to 5,500 b.p., PhD thesis at Yale University, 696 p. 
Wright, K.I. 2013, The Ground Stone Technologies of Çatalhöyük, 1993-2008. In: Substantive Technologies from Çatalhöyük: reports from the 2000-2008 seasons (Hodder, I., Ed.), Çatalhöyük Research Project Series Vol. 9, University of California at Los Angeles, Los Angeles: p. 365-416.

Yule, P. 2001, Die Gräberfelder in Samad al Shan (Sultanat Oman) - Materialien zu einer Kulturgeschichte. Orient-Archäologie Vol. 4. Marie Leidorf, Rahden, 514 p. (in German) ("The Grave-Field of Samad al-Shan (Sultante of Oman) - Materials of a Cultural History") 